\title{
Städningen och jämställdheten
}

I förra kapitlet såg vi hur städning både som praktik och symbol är tydligt knuten till kvinnligt genus. Vi såg kroppar vävas samman över och mellan tider och bilda sega strukturer som får de intervjuade personerna att uppleva städningen som en symboltyngd, identitetsskapande och långt ifrån värdeneutral syssla. De män jag intervjuade beskrev däremot sällan städningen som så laddad. Samtalen med dem blev kortare, med färre utvikningar och djupdykningar bakåt i historien. Städning tycktes helt enkelt inte beröra dem på samma sätt.

I samma stund som städningen blir en fråga om arbetsdelning i vardagen hettar det emellertid till även för männen. När sysslan ska fördelas mellan människor som lever tillsammans framträder den till och med som en av de viktigaste uppgifterna. Och när könsskillnad dessutom kommer in i bilden, liksom parbildning, blir frågan brännande.

Städning intar helt enkelt en central roll i diskussioner om jämställdhet mellan könen och i familjen. Kanske är det rent av så att jämställdhetens brännpunkt kan lokaliseras till just städningen; det vardagliga renhållningsarbete som sällan upplevs som särskilt belönande. Detta kapitel handlar om städningen och jämställdheten: om vilken roll städning spelar i skapandet av jämställdhet och ojämställdhet mellan könen. Mer specifikt vill jag fördjupa mig i de temporala aspekter av jämställdhet som aktualiseras genom vardagsstädning. Vems tid premieras 
och värderas och vilken betydelse har tid i konstruktionerna av en jämställd städpraktik?

Att jämställdhet $\mathrm{i}$ hemmet formuleras som en jämbördig relation mellan man och kvinna, huvudsakligen inom en heterosexuell parrelation, är också av analytiskt intresse. Jämställdhet är inte bara ett ideal om lika fördelning, utan säger också något om vilka som ska dela lika. Jämställdhetsidealet gör därför något med hur vi tänker oss att livet bör levas, både vad gäller genus, sexualitet och samlevnadsform (se exempelvis Dahl 2005, Martinsson, Griffin och Giritli 2016). Definitionen och konstruktionen av jämställdhet i hemmet har också, som blir tydligt framöver, betydelse för andra maktrelationer, såsom exempelvis klass, ras och nationalitet - något jag ska visa kommer att inverka på vardagsstädningens praktik.

Den förhandlande familjen

Som jag tidigare nämnt finns det tydliga belägg för att kvinnor gör merparten av hushållssysslorna inom den heterosexuella samlevnadsformen. En hel del förändringar har visserligen skett de senaste decennierna. Under 1970-talet utförde kvinnor över go procent av det rutinartade hushållsarbetet (t.ex. städning) medan andelen 2010 har sjunkit till 64 procent (SOU 2014, s. 97f.). Under ett halvt sekel har mäns andel av hushållsarbetstiden således ökat markant. Framför allt beror denna förändring emellertid på att kvinnors tid i hemmet i stort sett har halverats. ${ }^{13}$ Den totala tid som hushåll ägnar åt hushållsarbete är alltså mindre idag än för fyrtio år sedan. Samtidigt arbetar kvinnor fortfarande ca 45 minuter mer än män per dag i hemmet (Boye 2009, SCB 2012). Tvätten, tätt följd av städning och matlagning, hör till de sysslor som är mest könsuppdelade 
(SOU 2014, s. 98). Intressant att notera är att kvinnor lägger ner ungefär dubbelt så mycket tid i veckan på städning som män gör (SOU 2014, S. 107).

Det finns alltså tydliga, över tid återkommande, belägg för att kvinnor - idag liksom tidigare - gör merparten av det obetalda arbetet i hemmet. ${ }^{14}$ Undersökningar visar också att detta ofta är en källa till konflikter, missnöje och i vissa fall psykisk ohälsa (Boye 2010, Angelov m.fl. 2011, Harryson 2013). Samtidigt lever vi i en tid där denna ojämlika fördelning av betalt och obetalt arbete inte, som varit fallet tidigare i historien, ses som självklar och eftersträvansvärd (se t.ex. Björnberg och Kollind 2003, Roman 2004, Magnusson 2006). Den officiella jämställdhetsretoriken gör gällande att kvinnor och män bör dela på hemarbetet, ett mål som som exempelvis merparten av alla riksdagspartier ansluter sig till. Sverige och svenskarna berömmer sig om att vara ett av världens mest jämställda länder och hamnar också i topp i jämförande undersökningar om jämställdhet världen över. ${ }^{15}$ En studie gjord av Europeiska institutet för jämställdhet visar exempelvis att varannan svensk man arbetar med hushållsarbete varje dag, jämfört med snittet i EU som ligger på var färde man. En statligt sanktionerad norm om jämställdhet kolliderar emellertid trots allt med en verklighet där kvinnor (ännu) gör merparten av det obetalda hemarbetet, där städning är en viktig del.

För de flesta personer jag intervjuade var jämställdhetsaspekten synnerligen närvarande i diskussionerna om städning. Som allra tydligast var den emellertid bland de personer som levde (eller hade levt) i heterosexuella parrelationer. Många av dem tycktes också aktivt arbeta med att hitta en uppdelning som fungerade, där både mannen och kvinnan var nöjda. Och nöjd, för de flesta, innebar en någorlunda jämlik fördelning av arbetet. Detta resulterade i sin tur i ständiga för- 
handlingar kring vad som är ett städat hem, vem som ska göra vad, när och hur (jfr Björnberg och Kollind 2003). Arbetet är visserligen fortfarande kvinnokodat, men bör i jämställdhetens namn delas av både mannen och kvinnan.

Åsa Lundqvist och Christine Roman (2003, s. 13ff.) talar om den "förhandlande familjen", en sorts institutionaliserad individualism som successivt ersatt tidigare kärnfamiljsideal med fasta genuskodade roller och uppgifter. Dessutom har normerna kring städning förändrats sedan 1950-talets hemmafruideal satte standarden. Idag, menar exempelvis Rosie Cox (2011), har vi i mångt och mycket slopat de rutiner kring städning som tidigare var legio. Vi känner inte längre samma sociala tvång att städa efter ett förutbestämt mönster, vilket får tidigare etablerade begrepp som veckostädning, vårstädning, höststädning och julstädning att förefalla gammaldags och passé. Istället städar vi »efter behov", i relation till »hur det känns» och när vi »har lust». Lydia Martens föreslår, som jag tidigare nämnt, att vi har att göra med en ny kulturell städstandard som snarare baseras på estetik, synlighet och känsla än på att „tiden är inne för att göra jobbet«. De nya normerna innebär en viss frihet, men också en ständig osäkerhet: Har jag gjort tillräckligt? Är jag verkligen färdig? Är det snyggt nog? Och, inte minst:Vem bestämmer vad som är ett tillräckligt städat hem?

Denna historiskt specifika kontext skulle kunna beskrivas som en, med Thomas Ziehes (1986) begrepp, kulturell friställning och individualisering av själva städrutinerna. Samtidigt verkar idealet om att ha ett rent och snyggt hem kvarstå. Kvar är också genusdelningen av sysslan, något som verkar resultera i just ständiga förhandlingar.

Andreas, som levt tillsammans med Lydia i över tjugo år, beskriver hur deras nuvarande städvanor i hemmet bygger på en 
successiv jämkning över tid. De första åren bråkade de rejält om ordning och reda och kläder på golvet.

ANDREAS: I början hade vi olika syn på det, det hade vi verkligen. Jag ville nog ha mer städat än Lydia. Men det hade bara att göra med, tror jag, att jag inte riktigt visste vad det innebar att ha väldigt fint städat, eftersom min mamma städade mycket. Jag trodde att det skötte sig självt. Jamen, nu överdriver jag... Men det var nog en ganska gammaldags syn på familjeförhållanden, skulle jag tro.

För Markus, som tidigare var gift med Kristina, framstår de ständiga förhandlingarna om städningen, eller tjafset som han beskriver det, som så arbetsamma att han njuter av att numera sköta allt själv.

MARKUS: Det var alltid en massa tjafs om vem som egentligen borde städa och så där. Och detta trots att vi hade städhjälp varannan vecka! Men varannan vecka så, ja, jag vet inte. Ja, man behöver ju städa mellan dom här städhjälptillfällena också. Det var nog tjafset som var värst. Jag tyckte ju att det kanske borde ligga i hennes intresse också.

FANNY: Du tyckte du gjorde mer?

MAR KUS: Ja, jag tror det. Fast jag vet inte om jag egentligen gjorde mer. Jag kanske tyckte att jag gjorde mer än vad jag gjorde. Det var ett ständigt pågående, ständigt dividerande om vem som skulle göra vad och vem som inte gjorde vad den skulle.

Ett sätt att hantera det Markus beskriver som det »ständiga dividerandet« blir att försöka skapa nya rutiner, gemensamt bestämda och anpassade efter parets behov. Så beskriver exempel- 
vis Mary hur hon och hennes förra man försökte lösa problemet med städningen och jämställdheten.

MARY: Vi märkte ganska snabbt att om vi inte liksom institutionaliserade det eller organiserade det så blev det att jag städade mycket mer. Så då införde vi lördagsstädningar. Att »nu gör vi det tillsammans« och så höll man på kanske en, en och en halv timma. Och sen var tanken att man skulle försöka småplocka under veckan, men det gick väl sådär. Men storstädningen funkade just för att vi bestämde så. Men det där andra som är mer svårdefinierat, alltså småplock eller just det här att göra vackert, där var det väldigt traditionellt, liksom. Bara jag.

Medan Mary och hennes ex-man valde att införa gemensamma lördagsstädningar har Iris och hennes sambo försökt sig på att göra listor som successivt ska bockas av.

FANNY: Hur skulle du säga att ni har organiserat städningen? Om ni organiserar den?

IR IS: I början av vår relation hade vi långa listor med fördelning och ansvar för att det inte skulle bli att jag städade mer och han mindre. Men dom lyckades vi aldrig hålla vid liv så dom blev bara sorgliga. Jag har en här. Här har vi försökt nån gång. Det är alltid jag som gör listorna.

FANNY: Då står det »bottenvåningen: plocka, dammtorka, dammsuga, skura, vattna». Övervåningen samma sak.

IR IS: Det här är alltså en rad uppgifter som måste göras hela tiden, hela tiden, hela tiden.

FANNY: „Badrummet, återvinning, tvätt, tvättstugan, hallen, garderob, stora förrådet, lilla förrådet, spisen och kaklet, mikron, cd-hyllan, vardagsrumsbordet, torka luckor, kylen, vec- 
kohandla, rensa korgen, rensa hyllor, rensa skafferiet, ugnen, kryddhyllan, dvd-hyllan, bädda rent, klippa gräset, rensa ogräs, badrummet nere«. Sen så ser man vecka...

IRIS: Då tänkte vi att här är en hop av uppgifter som alltid måste göras. För att vi skulle synliggöra vad vi gjorde. Du ser, vecka 18, då skrev jag upp vilka punkter jag hade gjort.

FANNY: Då hade du gjort 22, 12, 15 och 4. Det betyder; kryddhyllan, mikron, torka luckor och badrummet uppe. Och han hade plockat, dammsugit, vattnat på bottenvåningen och övervåningen. Men sen ser man att det mattas av där framåt sommaren. Hur kommer det sig? Blev det för krångligt?

IRIS: Vi brukar börja så här och så tycker vi att »åh vad skönt, då har vi tagit ett grepp om det». Och sen så ...

FANNY: Är det du som tycker att det är skönt att ni har tagit ett grepp om det?

IR IS: Jag tror det, men jag tror att han också är för listor och ordning och sånt där i teorin. Sen är det svårare att följa upp det. Det räcker att nån börjar balla ur, då orkar inte den andra heller, för då blir det ännu deppigare att man faktiskt försöker. Det är inte i första hand för att komma åt obalans. Det finns med, men det är också för att få det gjort, kunna bocka av.

FANNY: Så det har havererat. Hur gör ni nu då?

IR IS: Egentligen tror jag att det går till så att vi städar båda två när jag får nog. Och då är det kanske framåt helgen. Och då delar vi upp lite grovt så att om jag tar övervåningen så tar du mellanvåningen. Och så gör vi precis bara vad vi orkar.

Iris, Mary, Markus och Andreas beskriver hur de, gemensamt med sina sambor, försökt systematisera de mödosamma och tråkiga uppgifter som hör till familjelivet, där städningen ofta är den minst eftertraktade. Försöken att undvika att falla till-

90 $\mid$ TID ATT STÄDA 
baka på tradition och inövade vanor vad gäller genus, rutiner och standard gör städandet till en ständig fråga om ordning och organisation, huvudsakligen centrerad kring tid. Ofta verkar det dessutom som om uppgjorda listor i sig blir en källa till bråk och besvikelser (jfr Magnusson 2006). Iris konstaterar att de på förhand gjorda scheman familjen har på skåpluckan snarast blir en sorglig påminnelse om något som aldrig realiserades. Vad hon hänvisar till är alla de små enskilda uppgifter som renhållandet av ett hem består av-som att dammsuga hallen, tvätta skåpluckorna, torka ur mikron och svabba badrumsgolvet. Att lyckas ta ett samlat grepp om detta svårgripbara, få kontroll och genomföra en gemensam plan. Kanske handlar känslan av uppgivenhet till syvende och sist om att moppandet och dammsugandet och plockandet i sig blir en symbol för ett gemensamt samliv, en bild av hur vi väljer att ta hand om och investera känslomässigt i det gemensamma.

\section{Män som städar}

Som jag tidigare varit inne på har den ideala (borgerliga) familjemodellen förändrats över tid. Om familjen under 180o- och stora delar av 190o-talen huvudsakligen tänktes vara en kombination av en hemcentrerad, hemarbetande kvinna och en förvärvsarbetande man riktad mot offentligheten, utgörs dagens ideala heterosexuella kärnfamilj snarast av två familjeförsörjare med delvis gemensamt ansvar för hem och barn. Helene Aarseth (2011, s.13), som undersökt levnadsformer bland heterosexuella medelklasspar i Norge, menar att det är denna »delvis jämställda familj« som växt fram som norm i de skandinaviska välfärdsstaterna. Det moderna tvåsamma familjeprojektet är i denna bemärkelse inte längre entydigt könskomplementärt, utan 
bygger idealt sett på individualiserade relationer, en gemensam samsyn och bådas lika rätt till egna livsprojekt.

Skillnaden liknar alltså den jag tidigare skissat kring städningens praktik - vi ser en ökad individualisering och kulturell friställning även på relationernas område (jfr t.ex. Bäck-Wiklund och Bergsten 1997, Johansson 2009). Med utgångspunkt i denna historiska omständighet frågar sig Aarseth hur familjeliv och arbetsdelning organiseras i den moderna heterosexuella, »delvis jämställda« familjen, där ansvarsområdena inte längre är givna och båda parter dessutom förväntas förverkliga sig själva (jfr Haavind 1985, Magnusson 2006). Hennes svar går via en undersökning av vad hon beskriver som individens emotionella investeringar. Aarseth menar nämligen att det gemensamma familjeprojektet i långt större utsträckning än tidigare bygger på känslomässig lust och motiveringar (jfr Björnberg och Kollind 2003, s. 87ff.). De gånger paren i hennes studie delar någorlunda lika på hemsysslorna är det för att motivationsformerna har ändrats, så att mannen känner ökad lust att inreda, laga mat, ta hand om barn och städa. Denna lust kan i sin tur delvis förklaras med en ökad intimisering och hemcentrering i kulturen i stort. I en värld av ökad kulturell friställning, lyder argumentet, blir investeringen i nära, känslomässiga relationer i det privata en ny form av självändamål (jfr Giddens 1992). Hemmet är emellertid inte, som exempelvis i 180o-talets borgarklass, enbart att förstå som en »känslomässig borg». Snarare inbegriper familjens nya intimitetsformer andra kombinationer av kärlek, omsorg och självförverkligande, där jämlikhet, jämställdhet och individens möjlighet till självutveckling är centrala. På så sätt blir självutvecklingen en viktig källa till intimitet, liksom intimiteten blir en källa till självutveckling. Såtillvida, menar Aarseth, kan sökandet efter intimitet sägas bli det sekulära 
samhällets »nya religion«, i vilken hemmet och investeringen i de nära relationerna spelar en central roll för både män och kvinnor.

Skulle då en förändring i motivation kunna förklara det engagemang i hem- och hushållsarbete som männen i min studie ger uttryck för? Till skillnad från sina pappor - och tidigare generationer av pappor före dem - beskriver de sig alla som långt mer investerade i såväl hem- som hushållssysslor, något som understöds av statistiken på området. Följer vi Aarseth skulle denna attitydförändring kunna tolkas som en vilja till intimitet och meningsfullhet i en värld kännetecknad av kulturell friställning. Samtidigt var det få av intervjupersonerna som beskrev städning som vare sig lustfylld eller särskilt meningsfull, trots att ett välstädat hem i mångas ögon är förutsättningen för trivsel och hemkänsla. Även om det kan vara skönt när jobbet väl är gjort, upplevdes städningen av de flesta som en påfallande otacksam och tråkig syssla.

Aarseths studie bekräftar också att städning mer sällan än annat hemarbete (såsom omsorg om barn, matlagning, renovering och trädgårdsarbete) var en källa till känslomässiga investeringar av positiv art. Snarare än lust och mening tycks motivet för att engagera sig i städningen kunna hänföras till en vilja att dela jämlikt på de sysslor som fă upplever som de mer lustfyllda i samlivet. Joel, som sedan generationer tillbaka arbetar som bonde på egen gård, beskriver hur han genom sin sambo har blivit medveten om att städningen av hemmet är något de bör dela på. Av rättviseskäl, som han förklarar saken. Hon har ju ett jobb att sköta utanför hemmet och han har sitt med djuren och skogen och maskinerna. Skötseln av hemmet faller därför på dem båda, i rättvisans namn. »De flesta människor tycker ju inte att det är skitkul att städa, så man känner sig ju inte så snäll om man inte delar.» 
Joel beskriver hur hans delaktighet i städandet skiljer sig från hur det var när han växte upp. Han säger sig inte minnas att pappan någonsin var med och städade hemmet. Allt hushållsarbete föll på mamman, som dessutom hade ett heltidsarbete i en ort några mil därifrån.

JOEL: Ja, hon tog ju allt. Dom såg det väl som att det han gjorde utomhus var jobb, det också. Det var väl aldrig snack om att han skulle arbeta inne, han var tvungen att göra sitt ute. Nånting måste han väl ha gjort med städningen, men jag kommer inte ihåg det alls. Jag har faktiskt inte pratat med honom om det heller. Det jag kommer ihåg var att mamma stod vid spisen och var ledsen över att vi barn inte hjälpte till mer. Och det förstår man ju såhär i efterhand.

Att ta sin beskärda del av det minst belönande av hushållssysslor är alltså ett viktigt motiv till de intervjuade männens städande. Intressant att notera är också att få av männen förklarar att de avskyr städning med samma självklara intensitet som vissa av kvinnorna. Flera av dem uttrycker sig dessutom påfallande diplomatiskt när de beskriver upplevelser av att göra mer än sin kvinnliga partner, såsom vi tidigare såg Markus svara när jag frågade honom om huruvida arbetsdelningen mellan honom och ex-partnern var skev: »a, jag tror det. Fast jag vet inte om jag egentligen gjorde mer. Jag kanske tyckte att jag gjorde mer än vad jag gjorde.»

Sammantaget framträder en bild av städning som en syssla män omöjligen kan avfärda som oviktig, förutsatt att de vill framstå som någorlunda jämställda. Eftersom städning sällan upplevs som belönande i sig, verkar det mest uppenbara motivet att göra sysslan vara rättvisa, i form av jämställdhet. Att visa 
sig välvilligt inställd till att dela på ansvaret för städningen blir liktydigt med att inte vara manschauvinistisk, att solidariskt ta sin del av kakan.

Ett egenhändigt städat hem kan i vissa fall till och med vara ett sätt att visa sig värdig och trovärdig som förälder och pappa. Så kan åtminstone intervjun med Göran tolkas. Göran beskriver hur hans mamma alltid skött hushålls- och omsorgsarbetet i barndomshemmet. Hon var frånskild och de veckoslut Göran tillbringade hos den alltmer alkoholiserade fadern minns han som stökiga och smutsiga. Att undvika att bli en sådan fadersfigur efter den egna skilsmässan verkar ha varit vägledande för Görans vilja att alltid ha det rent och fint inför barnens ankomst.

GÖRAN: Jag tror det är nån slags stolthet som gör att jag vill att det ska se snyggt ut här. Jag har ju erfarenhet från farsan där det inte var så kul att vara som barn. För det såg för jävligt ut och var ostädat och disk i stora drivor och så där. Jag vill nog att ... Det ska liksom ge ett bra intryck av mig och mitt sätt sköta hemmet. Det är min plikt som pappa tänker jag.

Genom städpraktiker skapas sålunda en specifik sorts mansideal-en man som genom att han är positivt inställd till att dela på städningen framstår som både ansvarstagande och jämställd. Genom att jämföra sin egen inställning med tidigare generationer av män blir den samtida mannen just mer jämställd, men också mer modern och framsynt. Jämställdhet som motivationsform är nämligen inte enbart ett politiskt ideal, utan blir också en väsentlig del av konstruktionen av det moderna Sverige. På så sätt framstår den både som ett naturligt och oundvikligt led i utvecklingen mot det bättre. Denna aspekt av jämställdhetens temporalitet är något jag återkommer till senare i kapitlet. 


\section{Med blick för smuts}

Som vi kan se tycks idealet om jämställdhet till viss del ha fått insatserna i hemmet att införlivas i den moderna svenska mannens motivationsform. Det är helt enkelt inte längre riktigt möjligt att, som modern man, propsa på att komma undan det tråkiga städandet. Samtidigt visar alltså statistiken fortfarande på skillnader mellan mäns och kvinnors insatser i hemmet - inte minst vad gäller städningen (jfr Ahrne och Roman 1997, Magnusson 2006, s. 231). Frågan är hur dessa skillnader görs och motiveras i praktiken. Några möjliga svar på detta hittar jag i intervjuerna med Peter och Minna, som levt tillsammans i närmre tjugo år med tre barn.

FANNY: Hur organiserar ni städningen hemma hos er?

PETER: Vi gör inte riktigt det skulle jag säga. Jag tycker inte att vi har nån organisation för städningen. Det är mer som att plötsligt är det nån slags brandkårsutryckning. Det finns två olika: det finns en brandkårsutryckning som handlar om att "men nu måste vi städa!» Jag har några avgränsade uppgifter som jag brukar ta när Minna och jag ska städa. Det ena är spisen, köket. För det gör att köket ser ganska rent och schysst ut, om man bara tar den där spisen och bänken. Och sen min special, som är liksom min grej och har varit det ända sen jag var liten, det är toaletten. Jag har blivit ganska bra på att städa toaletten.

FANNY: Brukar du få uppskattning för det hemma?

PETER: Att jag städar toaletten? Ja, Minna är lite manipulativ. "Du är så bra på att städa toaletten.» Och sen så gör jag det. »Kan du inte städa toaletten?« Och då bara: »Jamen jag fixar det.» Så får jag lite kärlek!

FANNY: Du sa att det fanns två metoder; det ena var brandkårsutryckning. Vad var det andra? 
PETER: Ja, den andra är lite mer: »Jamen på lördag måste vi städa.» Och då har vi en städdag. Då gör vi det kanske lite mer ordentligt. Men det där "på lördag har vi städdag», det skulle jag kanske gissa att vi gör en gång varannan månad kanske. Ungefär.

FANNY: Och vem är det som brukar ta initiativet till det?

PETER: Minna.

FANNY: Minna? Varför då?

PETER: Ja, varför är det hon som gör det? Jamen, det är för att vi stoppar lite huvudet i sanden båda två. Men jag stoppar kanske huvudet lite djupare än vad hon gör. (skratt) Jag vet inte om det har nåt att göra med våra könsroller, det har det förmodligen kanske.

Peter, som är helt inriktad på att städningen ska delas lika mellan honom och Minna, beskriver hur han visserligen är riktigt bra på spisen och toaletten - men att han samtidigt stoppar huvudet lite djupare i sanden än Minna när det handlar om att ta initiativ. Eftersom familjen inte har några särskilda städrutiner, hänger varje enskild städning på att någon tar ett beslut. Och denna någon tycks huvudsakligen vara Minna.

FANNY: Hur går det till när ni tar det där beslutet?

M INNA: Jag tror att det är oftast jag som säger det. „Du, vi kanske borde städa.॥

FANNY: Och vad säger han då?

M INNA: Ja ... vad säger han, han säger att ... Alltså, då gör vi det. Fast vi kanske inte städar samtidigt. Det kan vara så att det är jag som börjar städa och så säger jag: »Du, nu har jag städat här och så har jag gjort det här och det här, tar du badrummet och toan?« Och då gör han det. 
FANNY: Går det någonsin till tvärtom? Att han säger såhär: »Du, nu har jag städat.॥

M INNA: Nej, det gör det faktiskt inte. Det har jag inte tänkt på, men det gör det faktiskt inte.

FANNY: Så du tar mera initiativ kan man säga.

M INNA: Ja. Han är mer den uppskjutande typen, även om jag har vissa såna drag. Gud, jag kanske ska vänta tills den grejen kommer! Testa det, om det kommer i helgen ändå.

FANNY: Ja, se vad som händer.

MINNA: Det är lite skevt utifrån att jag nog mer tar det initiativet, men Peter tar mer initiativ kring andra delar som kanske traditionellt också brukar falla på kvinnor. Som matlagning, fylla frysen, köpa hem grejer, handla. Han gör säkert 70-8o procent av sånt. Och så har han koll på barnens fotbollsträningar.

Beslutet och initiativet att städa verkar, som synes, falla på Minna. Det är hon som måste sätta bollen i rullning, ett ansvar hon verkar smått irriterad över. En liknande dynamik gäller i Joels familj:

FANNY: Hur organiserar ni städningen?

JO E L: Jag är sämst på att säga till att vi måste städa. Jag gör det däremot gärna om nån säger att nu är det dags. Egentligen skulle man väl kunna bestämma en dag i veckan, men det blir liksom inte av. Så jag städar när jag har tid och nån säger till.

FANNY: Och vem brukar säga till?

JOEL: Haha, Angelica.

FANNY: Och hur ofta blir det då?

JOEL: Det blir övervåning varannan vecka och undervåningen varannan. Så, en gång i veckan blir det. 
Att det huvudsakliga ansvaret för städningen ofta faller på kvinnan i den heterosexuella parrelationen bekräftas av tidigare studier. Eva Magnusson (2006, s. 177) som undersökt hur heterosexuella par i Norden delar på hemarbetet, noterade att även bland de par som delade som mest lika på hemarbetet riskerade både ansvar och initiativ att hamna på kvinnan, så att hon fick rollen som arbetsledare (jfr Björnberg och Kollind 2003, Platzer 2007).

I intervjuerna med Minna och Peter ser vi också hur Peter verkar få ansvar för vissa enskilda områden och "projekt", såsom han exempelvis beskriver med toaletten eller spisen, medan Minna tar det andra. På liknande sätt beskriver Marie sin och sambon Fredriks uppdelning.

FAN NY: Hur ser det ut hos er? Vem städar?

MARIE: Jag städar mer än vad Fredrik gör. Men han har ibland projekt. Om jag kommer så kan han ha dragit ut spisen och hittat på saker. Han har en blick för städning, absolut, men han går mer in i stora projekt. Det kan liksom stå en massa disk och ändå går han och lägger sig. Men jag tycker att börjar man städa nåt, så ska man ta disken också, torka bordet också. Alltså, ha lite mer helhetssyn.

Uppdelningen mellan projektinriktning och helhetsansvar återfinns även i andra undersökningar (se t. ex. Pink 2004, Platzer 2007, s. 94, SOU:2014, s. 96). Bland annat beskriver Helene Aarseth hur kvinnorna i hennes studie tenderade att ta större ansvar för helheten $i$ hemmet, medan männen engagerade sig i byggprojekt eller avancerad matlagning. SCB:s tidsanvändningsstudie från 2012 visar också att männens ökade insatser i hemmet till stor del handlar om underhållsarbete (såsom reparationer) och matlagning, snarare än städning (och tvätt). 
Det finns alltså en tendens att männen i heterosexuella parrelationer, när de väl tar del i hemarbetet, gör mer avgränsade sysslor - som vi exempelvis tidigare såg Peter ansvara för spisen och toaletten. Kanske är det så vi ska förstå det faktum att män också (enligt samma studie) har mer sammanhållen fri tid i hemmet. Medan kvinnorna rapporterar fler och kortare sjok av ledig tid, inklämd mellan tvätt, pastakokande och blöjbyten, är männens fria tid längre och avbryts oftare av måltider. Så ser vi hur kvinnor tenderar att vara mer ständigt upptagna av en helhetskoll på läget, medan männen gör avgränsade insatser i hemmet.

Vems ansvar?

Hur ska vi då förstå detta fenomen: att städandet tenderar att bli kvinnans ansvar medan mannen tar sig an mer tydligt avgränsade projekt som matlagning, renovering eller handling? Helene Aarseth, som intresserar sig för de känslomässiga motiven och drivkrafterna kring hemarbetet, menar att kvinnorna i hennes studie upplevde sysslandet med de mer vardagliga tingen som just mer lustfyllt än männen. Därför, tänker hon sig, utvecklade de också en skarpare blick för de till synes osynliga, pliktfyllda och obetydliga sysslorna i hemmet. Att männen i högre utsträckning fann tillfredsställelse i de större, mer avgränsade, projekten analyserar Aarseth som en »nykomlingsstrategi« (2011, s. 61). Det tycks helt enkelt lättare att erövra, ta sig an och därigenom finna lust i en avgränsad uppgift med början och slut, än att tillägna sig en allmän blick för det vardagliga. Så skulle vi eventuellt kunna förstå hur det kommer sig att toaletten, från att i Hirdmans retoriska titel ha symboliserat den minst åtråvärda hemarbetssysslan, 
blir ett möjligt avgränsat städprojekt för den moderne mannen utföra.

Aarseth drar också slutsatsen att det inte nödvändigtvis var arbetsinsatsen som saknades hos männen hon studerade, utan snarare »känslan« för arbetet (jfr Magnusson 2006). Kanske är det därför många män i heterosexuella parrelationer, trots ideal om jämställdhet, tenderar att lägga större ansvar för städningen på sin kvinnliga partner. Att de, helt enkelt, saknar den känsla för skit som traderas över tid och generationer och således heller inte har lika lätt att uppbåda energi eller entusiasm för arbetet. Vad vi bortser från i detta resonemang är emellertid att städningen, i Aarseths studie, sällan uppfattades som särskilt lustfylld eller självuppfyllande, varken av kvinnor eller män. Till skillnad från andra arbetsuppgifter i hemmet, såsom pyntande, renovering, matlagning eller omsorg om barn, upplevdes städningen mestadels som ett nödvändigt ont.

Att kvinnor, över tid, har upparbetat en »känsla» för jobbet innebär alltså inte automatiskt att de också uppfattar uppgiften som belönande eller lustfylld. Snarare kan vi tolka kvinnors större ansvar för städning i hemmet som en kombination av känsla och övergripande ansvar. Den kroppsliga praktik som traderats i kvinnoled måste alltså förstås både som en insocialiserad estetisk blick för den materiella omgivningen och en av nödvändighet upparbetad ansvarskänsla för just denna sorts syssla. Ansvaret föder blicken och blicken skapar ansvar.

Eva Magnusson (2006) använder begreppen begränsningar och avgränsningar för att diskutera samspelet mellan (heterosexuella) kvinnor och män i vardagen. Hon beskriver hur kvinnor traditionellt har haft fler begränsningar än män. De har tillåtits att röra sig på färre och trängre områden, både socialt, geografiskt och yrkesmässigt. Kvinnors avgränsningar, det vill 
säga de möjligheter en person har att värja sig mot andras försök att vidga sina egna områden på hens bekostnad, har också varit svagare än mäns. Att vara en god kvinna, i bemärkelsen mor, hustru, dotter, svärdotter etcetera, har genom historien inneburit att förväntas ta större hänsyn till andras önskningar än sina egna. Det har helt enkelt varit mer acceptabelt för andra att överträda en kvinnas avgränsningar än en mans - att ställa krav på hennes tid, engagemang, arbetsinsats eller sexuella uppmärksamhet. Genom historien har således kvinnors avgränsningar varit svagare än mäns och mäns begränsningar mindre än kvinnors. Idag, menar Magnusson och flera med henne, har mönstren förändrats. Kvinnor har större utrymme och färre begränsningar och kan alltså röra sig inom fler och större områden. När det gäller kvinnors avgränsningar verkar det emellertid inte ha skett lika stora förändringar. Kvinnor förutsätts fortfarande ofta ha sämre avgränsningar mot andras krav än män (jfr Haavind 1985, Holmberg 1993). Detta skapar en något tvetydig situation för kvinnor i det samtida Norden. Det kan se ut som om de får göra allt en man kan tänkas göra - samtidigt förväntas de ta större hänsyn till alla runt omkring dem.

Intressant i detta sammanhang är hur städningen, de gånger den beskrevs som lustfylld och vilsam av intervjupersonerna, huvudsakligen utfördes i ensamhet eller utan hänsyn till en familj, barn eller andra närstående. Johanna, en kvinna i dryga fyrtioårsåldern som lever ensam i en mindre lägenhet, förklarar sin förtjusning i att städa sitt hem med att det helt och hållet är på hennes egna premisser: hon bestämmer själv både standard, tidsåtgång och omfattning. Och Mandy beskriver hur städningen, från att tidigare ha utgjort en ständig källa till återkommande gräl, numera upplevs som en akt av självomsorg och vila. Skillnaden, som hon förklarar den, är att hon separerat från sin 
man och idag lever ensam med barn, vilket betyder att hon själv bestämmer över städningen (detta är något jag återkommer till i kapitel fem).

Utifrån dessa resonemang får vi ytterligare perspektiv på hur kvinnors »känsla» för smutsen i hörnen kan förstås. Med sämre avgränsningar, något som blir extra synligt i en parrelation med en man, blir det helt enkelt svårare att bortse från dammet på golvet. Så, tänker jag mig, blir det möjligt att förklara att Peter säger sig se och samtidigt inte se dammtussarna på vardagsrumsgolvet - liksom hur detta »delvisa» seende får honom, som han själv beskriver det, att stoppa huvudet lite djupare i sanden än Minna.

FAN NY: Vad skulle du inte stå ut med för typ av smuts? När blir det för smutsigt för dig?

PETER: Hmm ... När man knappt kommer in i hallen för att det står skor överallt. Och de här små plupparna som kommer från fotbollsskorna, från konstgräs ... Det är som små plastpluppar. När det är såna på hela golvet. Kattlådan luktar illa. Det väller ut plastförpackningar på köksbordet från diskstället. Men det där med damm och sånt, där tror jag att min toleransnivå är väldigt hög, alltså. (skratt)

FANNY: Det är inget du stör dig på. Eller ser du det inte?

PETER: Jag väljer att inte se det, så är det ju.

FANNY: Men du ser det?

PETER: Ja, jag ser det, fast jag ser det inte, om du förstår vad jag menar. Jodå, jag kan nog tala om ungefär hur dammigt det är hemma på vårt golv om du frågar mig nu. Men det är som att jag väljer att inte uppleva det, på nåt sätt. Jag sorterar bort det. FANNY: Hur pass dammigt är det på ert golv just nu då? PETER: Det är dammigt. Det ligger nån gammal luddig filt som 
katten har varit på, och det ligger lite godispapper ... Alltså, jag vet var saker och ting ligger faktiskt, när jag tänker efter. Fast jag har inte tagit upp det. (skratt) Så är det nog.

Städning som jämställdhetens slagfält

Trots mäns ökade insatser i hemmet är alltså fördelningen mellan könen i heterosexuella familjer, som synes, fortfarande ojämn. Även om kvinnor gör mindre hushållsarbete än tidigare, utför de ändå knappt en timme mer per dag än män. Allra mest ojämlik ser uppdelningen av städandet (liksom tvätten) ut att vara. Det är heller inte enbart själva städandet som oftare faller på kvinnan utan också, och kanske framför allt, initiativet till arbetet. Hanne Haavind (20o6) beskriver det som att männen visserligen i allt högre utsträckning kan ta ansvar, medan kvinnan är den ansvaret faller på. Och Eva Magnusson (2006, s. 198) talar om något hon kallar mäns »avståendemaktu: att män helt enkelt kan avsäga sig sysslan om den inte passar, i förvissning om att någon annan tar vid.

Städningen är alltså, som syssla betraktad, en viktig ingrediens i görandet av ojämställdhet. Intressant för mitt övergripande perspektiv är hur detta tar sig form via tid. Som jag visat är tiden och förhandlingarna om tid central i diskussionerna om en jämställd städning. När ska sysslan utföras, hur ofta, hur mycket tid lägger varje person ner och hur ser den tidsmässiga uppdelningen ut?

Om det slutgiltiga målet är jämnt fördelad tid mellan kvinna och man i det heterosexuella parförhållandet (något som kan tänkas accentueras genom jämställdhetsstatistikens fokus på tid och tidsåtgång), verkar detta vara lättare sagt än gjort. Att dammsuga kök och skura toalett må vara projekt någorlunda 
lätta att avgränsa tidsmässigt, men plockandet, iordningställandet, torkandet och planerandet framstår snarare som ständigt återkommande evighetssysslor, smått omöjliga att räkna. Det övergripande ansvaret-att initiera, följa upp, hålla ordning på listor och bocka av - tycks dessutom minst lika tidskrävande som att utföra själva jobbet. Inte heller är bördan av generationers traderade kvinnoslit något som enkelt mäts i tid. Poängen i detta sammanhang är hur fokuseringen på räkningsbar tid, på timmar och minuter, tenderar att osynliggöra städningens temporalitet och därför riskerar att skjuta över målet.

Städningen är emellertid inte enbart en viktig ingrediens i görandet av ojämställdhet, genom en ojämlik uppdelning av ansvar, blick och tid. Det är även möjligt att se städning som en syssla genom vilken jämställdhet mellan kvinnor och män i parrelationer iscensätts. Förhandlandet om städning är med andra ord en nyckel till hur jämställdhet skapas, förstås och tar form i det samtida Sverige. Jag ska därför, framöver, fördjupa mig en aning i vad jämställdhetsidealet kan tänkas göra med städningen.

Som jag tidigare beskrivit tycktes ett av de viktigare motiven för de intervjuade männen att ta större del i städandet vara just jämställdhet. För att inte framstå som gammaldags och ojämställda anstränger de sig helt enkelt för att dela mer lika (jfr Norberg 2005, Neuman 2016). Intressant nog syns även tecken på motsvarande rörelse bland flera av de intervjuade kvinnorna. I samma stund som den jämställda relationen blir ett ideal, blir det dubbelt viktigt att städningen delas lika inom familjen. Inte enbart på grund av den reella arbetsbördan, utan också för att, genom att dela på arbetet, skapa en jämställd relation. I följande samtal med Iris får vi en fördjupad förståelse för hur uppdelningen av städuppgifter kan växa till en komplex väv av 
normer kring jämställdhet, heterosexuell samlevnad, genusidentitet och skam.

FANNY: Bråkar ni nånsin om städning? Är det ett konfliktområde?

IR IS: Inte längre. Dom första åren var det ju det. Bråk vet jag inte, det är mer att man blir deprimerad och låg och ledsen och så rörs det in en massa annat. Vi bråkade om städning, det gjorde vi, men det var nog hopflätat med många andra områden. Men nu bråkar vi aldrig om det. Det blir mer att man flinar åt det. Eller, det är lite som att man har gett upp. Jag orkar inte bråka om det, jag blir inte arg heller längre på samma sätt. Jag orkar helt enkelt inte gå och känna mig som en orättvist behandlad kvinna med en man som inte städar. Det är ju skittråkigt att se det på det sättet. Alltså, jag vill ju hellre se honom som allt möjligt annat och inte just det.

FANNY: Och om det nu är så, vad gör du av den känslan då? IRIS: Om jag blir arg på honom nu, då är det mer för hans allmänna passivitet. Och då blir städningen en del av det. Jag vill mer och mer börja se att han ... Ja, men herregud, han städar, det är inte som att ... Jag vet många värre fall. Men han städar mindre än vad jag skulle ... Jag skulle vara glad om han städade mer. Jag tror inte att jag vill se på honom som en man som inte tar hushållsansvar. Jag orkar inte det. Dessutom tar han ansvar för en massa andra områden.

FANNY: Du vill inte se honom som en man som inte tar hushållsansvar?

IRIS: Jamen, det är ju så tjatigt. Bara det här talet om det blir ju så gnälligt. Jag blir gnällig. En gnällig kvinna och mamma som ändå på nåt sätt gillar läget. Det vill man ju inte vara. Det blir som ett tugg: "gubben som inte gör vad man säger åt han«. Och 
det vill jag inte göra mot vare sig honom eller mig själv. Man vill inte vara den här »regeringen«, som äldre män brukar säga om sina fruar.

Iris har, som hon beskriver det, gett upp. Hon vill varken gräla med Johan om städningen eller klaga tillsammans med väninnorna på sin »hopplösa man«. Att bråka skulle helt enkelt bekräfta den ojämlika könsuppdelning hon inte vill vara en del av och få både henne och Johan att framstå som stereotypa män och kvinnor. På så sätt ser vi hur en påstått ojämställd relation inte enbart tenderar att belasta mannen. Risken är rätt stor att även kvinnan, som »borde veta bättre«, får stå där med skammen över att göra mer hushållsarbete än hon enligt idealet borde. Och detta, att framstå som en stereotyp underordnad kvinna i en heterosexuell parrelation, tycks vara något Iris i det längsta vill undvika. Innan hon blev ihop med Johan levde hon i en längre relation med en kvinna, där städningen inte heller fungerade smärtfritt.

IRIS: Det var inte på samma sätt i den relationen, att jag liksom blev den här regeringen, utan då kunde det bara få vara så att jag var den som städade mer och den andra städade mindre. På nåt sätt var det enklare att både gräla och prata om, för man hörde inte sig själv utifrån som en klyscha. Man kunde vara bara sitt förnamn och inte »kvinnan i förhållandet». Men nu undviker jag snarast konflikter, tror jag, lite av den anledningen. Att jag är så typisk på nåt sätt och att det är så deppigt att man hamnar i det. Men det var egentligen lika deppigt innan, med henne. FANNY: För vem känns det obehagligt? Är det inför dig själv eller inför andra utomstående?

IR IS: Jag vet inte. Det är nog inför mig själv. Inför honom också, 
man vill liksom skydda honom från att behöva vara en sån man. Han är ju inte det, på nåt sätt. Och jag vet att han verkligen inte skulle tycka om det. Ja, skydda honom och skydda mig från att vi är könsstereotypa - ett jämställt par som egentligen inte är jämställt. Mest kanske skydda mig inför mig själv. Skammen i att inte få till det.

I sin studie av heterosexuella pars vardagsliv konstaterar Eva Magnusson (2006) att jämställdhet i många fall föreföll vara något som kvinnorna blev ansvariga för att realisera. Även i de familjer som framstod som mest jämställda föll det på kvinnan att få mannen att ta sin del av ansvaret hemma (jfr Haavind 1985). Dessutom tenderade kvinnan att känna sig misslyckad och skuldtyngd om hon levde i en ojämställd relation. ${ }^{16}$ I intervjun med Iris ser vi hur just denna dynamik tar vägen via städningen. Hon har slutat att gräla eftersom hon varken orkar uppmärksamma eller bekräfta den ojämlika uppdelningen. Hon vill rädda Johan från att »bli» den stereotypa man han de facto är genom att han tar mindre ansvar för städningen. Hon vill rädda sig själv från att framstå som en klagande kvinna som trots allt framhärdar. Framför allt orkar hon inte leva med skammen i att inte ha den jämställda relation som hon både vill och förväntas ha.

Att Iris tystnar eller »flinar åt det» snarare än grälar - trots att hon egentligen är både arg och trött - måste helt enkelt betraktas som en räddningsaktion för idén om den moderna jämställda heterosexuella kärnfamiljen, det vill säga den familjekonstellation där en kvinna och en man, av fri vilja och självmant, delar lika på de arbetsamma sysslorna i hemmet. Iris har helt enkelt hamnat i ett moment 22 - väljer hon att klaga och bråka skriver hon in sig i sekler av kvinnor som trots gnäll accepterar att vara mannens »städerska». Mot bakgrund av risken att fram- 
stå som en stereotyp gammaldags kvinna som lever i en ojämställd relation - eller kanske ännu värre: »ett jämställt par som egentligen inte är jämställt» - väljer hon hellre tystnaden.

Vi skulle också kunna tolka hennes beskrivning av att flina åt "eländet» som ett delvis ironiskt förhållningssätt till en situation hon inte rår på. Att skratta åt sig själv, åt den hon är och har blivit i relation till mannen, blir då en inverterad form av motstånd mot tanken att hon ensam skulle kunna förändra en så låst struktur som den ojämlika genusordningen. Flinet skriver in henne i ordningen och ger henne samtidigt en aning respit från ansvar.

Tydligt i Iris resonemang är att den kvinnoroll hon vägrar att identifiera sig med skapas inom ramen för den heterosexuella parrelationen. När Iris, tidigare i livet, levt med en kvinna som heller inte delade på städningen i någon större utsträckning beskrivs den ojämlika uppdelningen inte som lika laddad. Trots att hon egentligen upplevde situationen som minst lika "deppig», slapp hon all den barlast av kvinnoslit som klibbar fast vid den ojämlika uppdelningen med mannen. Hon kunde, som hon beskriver det, vara bara sitt förnamn och inte »kvinnan i förhållandet». Således ser vi hur det ansvar och den känsla för renhållningen som traderas i kvinnoled inte enbart riskerar att återskapa en ojämlik arbetsdelning mellan kvinnor och män, utan även genererar en ständigt närvarande skuld för de kvinnor som inte lyckas bryta mönstret. Vi skulle också kunna formulera det som att städningens praktik tycks rymma fler potentiella vinster för mannen än för kvinnan i den heterosexuella parrelationen. En man som städar utan knot framstår som modern, framsynt och jämställd. En kvinna som glatt städar tenderar att associeras med förspilld kvinnokraft och en traditionell genusordning. Låter hon däremot bli, riskerar hon att 
uppfattas som en misslyckad omsorgsgivare och husmor. Sammantaget blir förhandlingar om den jämställda städningen en arena där den heterosexuella kärnfamiljen iscensätts och görs.

\section{„Kvinnan« i förhållandet}

Med utgångspunkt i dessa tankar är det intressant att flytta fokus till arbetsdelningen bland de samkönade par jag intervjuat. Vad "gör« städningen med föreställningar om genus och jämställdhet i dessa parrelationer? Adam, som lever tillsammans med Christoffer, beskriver hur det kan gå till när Christoffer kommit hem från en jobbresa och lämnat resväskan ouppackad i sovrummet.

ADAM: Vad som händer är att jag tröttnar efter ett par dar och då vill jag ta bort den. Och det är intressant tänker jag. Han har lämnat nånting framme som jag egentligen skulle vilja att han städar undan. Men jag har inte den där drivkraften att jag städar undan själv, utan jag tycker att det är hans grejer som han får ta ansvar för. Men jag vill heller inte bli den där tjatpersonen som säger att nu måste du ta bort det där, utan jag försöker låta den vara tills det händer av sig självt. För jag vägrar gå in i den där förenklade rollfördelningen. Att det är en som städar och en som inte städar eller en som tjatar och en som släpar efter. FANNY: Vad skulle vara jobbigt med det?

ADAM: Jag tänker att går man in i den rollen då ska man liksom ta det där ansvaret. Då ligger det på mig att ha det övergripande ansvaret. Att vara den som lägger märke till att nu måste den där tas bort. Jag vill hellre att det ska vara ett slags delat ansvar. FANNY: Har du tänkt på det i relation till kön? Hade det varit annorlunda om du hade levt med en kvinna eller om du själv varit en kvinna? 
ADAM: Just det. Det kan jag verkligen tänka mig att den där rollfördelningen, om en kvinna och en man lever tillsammans, så finns det nån slags outtalad förväntan om arbetsfördelning. Sen är det ju säkert många som omförhandlar och så. Men det kan ju lätt bli så att kvinnan trillar in i att hålla den där ordningen. I ett homoförhållande blir den där rollfördelningen inte lika tydlig. Det finns inte nåt slags blueprint man kan gå på utan att diskutera det. Ja, man måste diskutera det på ett annat sätt.

Adam beskriver, som vi ser, en situation som liknar tidigare berättelser från exempelvis Minna och Iris. Han riskerar att åka på merparten av städandet, eftersom han är den som noterar och stör sig på smutsen i hörnen. Samtidigt finns det ingen, som Adam beskriver det, direkt »blueprint» för hur städningen ska organiseras två män emellan, vilket betyder att förhandlandet blir mer förutsättningslöst (jfr Weeks, Heaphy och Donovan 2001, Flood 2003). Uppdelningen är något som dels måste diskuteras, dels inte har en given utgång. Framför allt känner han sig inte, som Iris beskriver det, fångad i rollen som »regeringen«.

I sin avhandling om samkönade pars arbetsdelning i hemmet kontrar Anna Norberg (2005) på tidigare studiers tendens att framställa samkönade par som mer jämställda än heterosexuella. Istället, menar hon, måste vi se talet om att dela lika som ett sätt att retoriskt förhålla sig till den heterosexuella kärnfamiljsnormen. De par hon intervjuade hade olika arbetsdelning och ansvar. Samtidigt omtalade många av dem sig själva som mer jämställda än heterosexuella par. I mitt intervjumaterial har jag snarare noterat en motsatt tendens. De samkönade paren tycktes mer ogenerat diskutera eventuella ojämlikheter i arbetsdelning än de heterosexuella paren. Mot bakgrund av Iris känslor av skam över att vara ett »jämställt par som egentligen 
inte är jämställt» blir denna tendens relativt begriplig. Kanske är det aningen mindre laddat att inför mig lämna ut både sig själv och sin partner, när ens vardagsslit inte trillar in i sekler av cementerad genusordning. Så tycks i alla fall vara fallet med Annika och Stacey, som lever tillsammans med ett barn.

FANNY: Hur ser städningen ut hos er?

ANNIKA: Stacey städar aldrig.

STACEY: But that is not true, Annika.

ANNIKA: Om inte jag ber dig...

STACEY: It depends on the definition of cleaning. I think that's what we're going to get down to ...

ANNIKA: There is no weird definition of cleaning. Cleaning is cleaning.

STACEY: OK, when it comes to mopping the floor, no I don't think I've ever...

ANNIKA: Dammsuger du?

STACEY: Not unless you force me.

ANNIKA: Torkar du golv?

STACEY: Does that mean mop the floor? No, never.

ANNIKA: Dammtorkar du tv-apparater, hyllor?

STACEY: Ja, det gör jag. I clean all of the devices.

ANNIKA: Men det är borden, du torkar av borden ibland.

STACEY: Jag blir galen!

AN NIKA: Dammtorkar du hyllor och fönster?

STACEY: NEJ!

AN I KA: Nä. Dammtorka, dammsuga och torka golv, det är att städa. Det andra är att torka av saker därför att man har spillt på bordet. Det är inte att städa.

STACEY: Didn't realize, it's a really complicated rule.

ANNIKA: Jag är inte complicated alls! 
FANNY: Om vi säger så här, Annika anser att du inte städar alls. Anser du att du städar?

STACEY: Jag anser att jag plockar upp ...

ANNIKA: Du plockar upp och torkar av.

STACEY: Jag plockar upp och torkar av.

AN N IKA: Vilket är vardags... Det är det alla gör, jag gör ju det också. Jag gör det mer än vad du gör. Om du torkar tre gånger i veckan så torkar jag tio gånger i veckan.

STACEY: Jaha. All these years I thought that was cleaning.

FANNY: Och vad gör du för typ av städning då, Annika?

AN N IKA: Helst har vi ju städerska, eftersom jag inte vill vara sur för att Stacey inte städar. Jag vill inte vara gnällkärring för det är det värsta jag vet. Och eftersom Stacey blir jättesur om jag säger att vi måste städa så har vi städhjälp. Men om vi inte har det så är det jag som städar helt och hållet, allting.

STACEY: All these years I didn't actually realize that your definition of cleaning was actually mopping the floor and ...

AN I IKA: Alltså plocka upp och torka av gör man ju varje dag. Varje dag så plockar man av. Städa är det som man inte gör varje dag. Det vill säga: inte plocka upp och torka av för det gör man varje dag. Sätta in i diskmaskin, ta ur diskmaskin, det gör du inte heller så gärna.

STACEY: Diskmaskinen? Nej, nej...

FAN NY: Vänta, får jag fråga, håller du med om hennes beskrivning?

STACEY: Ja lite. Yes, you're right. When it comes to the whole floor situation, I can't say that I've ever mopped the floor.

ANN IKA: Eller dammsugit.

STACEY: Jag dammsög ju förra veckan, you forced me.

AN N I KA: Ja, men det var ju för att jag bad. I forced! Jag sa: snälla nu har jag städat hela lägenheten, kan du åtminstone damm- 
suga sovrummet? Så det gjorde hon. Men sen lämnade hon dammsugaren, så att jag får sätta in den i skåpet.

STACEY: That was not true. I actually put it up. Nu ljuger du.

FAN NY: Hur kommer det sig att du inte vill göra dom här sakerna?

STACEY: I don't know, I've never done them. Even when I lived by myself, I guess the maid ... That is what she did all that time. FANNY: Hade du en maid när du bodde själv i USA?

STACEY: Mmm.

Diskussionen mellan Stacey och Annika hettar till direkt när jag sätter på bandspelaren vid köksbordet. Städning är uppenbarligen ett återkommande trätoämne, något av de mer laddade i relationen, och ingen av dem skräder orden. Stacey, som flyttat till Sverige från USA för Annikas skull, förklarar sig varken ha vilja eller förmåga att städa. Annika, som då och då försöker skapa en jämlik uppdelning av arbetet, ilsknar till vid tanken på att hon nästintill har gett upp. Intressant att notera är med vilken ogenerad rättframhet Stacey intar positionen som ovillig och arbetsvägrande. Som när Annika berättar om hur det var när de först flyttade ihop i hennes lägenhet:

ANN I KA: Okej, Stacey flyttar till Sverige, hon har inget jobb och vi har ingen städhjälp. Vi bråkade rätt mycket om det: du måste städa, liksom. Och då säger hon dom fantastiska orden: »Men jag tycker inte om att städa.» Som om: »Nähä, men vad synd. Men det gör jag, älskling, låt mig städa allting åt dig.» Och då blir jag irriterad och säger: »Men vadå inte tycker om att städa?« Då säger hon: »Men jag är inte bra på det.» Och då säger jag bara: „Då får du väl träna då.» Men då blev vi ovänner igen och så bråkade vi jättemycket och sen gjorde vi upp regler att varje söndag skul- 
le vi plocka upp grejerna och städa. Det var bara det att när söndagen närmade sig började hon bli sur redan på onsdagen. Och på fredagen och på lördagen var hon så sur så det gick knappt att prata med henne. Och då kände jag att det här orkar jag inte. Jättesur, jätteotrevlig för att om tre dagar ska vi städa.

Argumenten Stacey anför för att slippa städa faller, som vi kan se, inte i god jord. Att säga sig inte vilja, kunna eller ha lust att städa övertygar varken Annika eller en tänkt omgivning. Själv kommer jag på mig med att fråga Stacey om hon hör att hon låter som en bakåtsträvande gammaldags man, något hon flinar lite urskuldande åt. Hennes uttalanden, och det smått defensiva försvar hon försöker sig på, synliggör att den position hon intar vore i det närmaste omöjlig för en samtida heterosexuell man, som vill framstå som begriplig, uppdaterad och modern. En sådan man kanske inte nödvändigtvis städar mer än vad Stacey gör. Däremot skulle han förmodligen inte argumentera som hon - eller så öppet erkänna sig så okunnig på städningens område. Liksom jag tidigare visade hur Adams irritation på sin partners "slarvighet" inte nödvändigtvis upplevdes på samma sätt som Iris avgrundsdjupa trötthet, tydliggörs här att jämställdhetsdiskursen gör något med både Staceys och Annikas hållningar. Den position Stacey intar är visserligen omöjlig för en kvinna (som förväntas ta huvudansvaret för städningen). Samtidigt - och paradoxalt nog -är den möjlig just för att hon är kvinna. Det faktum att Stacey är en städvägrande kvinna och inte man resulterar nämligen i att hennes beteende delvis kan tolkas i linje med, snarare än på kollisionskurs med, jämställdhetsdiskursen.

FANNY: Har du ingen känsla att du som kvinna ska kunna städa ditt hem? 
STACEY: Nej.

AN NIKA: Stacey är helt befriad från såna här kvinnliga dilemman.

STACEY: I don't have those problems. I come from a very macho/ feminine culture. My family is a very matriarchal family. For some reason, I don't have any of these feelings of what a woman should do. I was obviously ignoring that part.

AN N IKA: Eller så är din hjärna lite wired differently. För det har jag också tänkt på. Du plockar inte upp saker på vägen, du kliver över soporna, allt sånt där som jag lärde mig redan som liten. Min mamma gjorde sju saker samtidigt och så fort man sa „mamma» så svarade hon direkt. Vi kan ju sitta här och Miranda kan säga mamma hundra gånger och jag får säga: „Stacey! « „Va?« säger du då och tittar upp. Och det är en typisk killgrej liksom, att man på nåt vis lyckas blockera ut det där »mamma, mamma, mamma».

STACEY: But I am not, I mean in no way am I masculine. I don't understand.

A N N I KA: Nä, det är du inte alls. Men det är sånt där, vad ska man kalla det? Det kvinnliga gisslet eller kvinnliga dilemmat. Medan jag går in i köket plockar jag med mig disken och sätter igång maskinen, lägger i tvättkorgen. Det gör inte du. Du tar din dator och går och lägger dig. Maten står kvar, diskmaskinen är inte igång. STACEY: Obviously, you're damaged in some way. You're raised with because you're a female you have to care for everybody. I don't feel that way.

AN N I KA: Ja, precis. Jag säger att det är ett gissel att vara som jag, jag säger inte att det är bra. Jag säger bara att dom flesta kvinnor jag känner är lite som jag. Vi gör en massa saker under tiden vi gör annat. Det gör inte du. Du plockar inte naturligt med dig Mirandas lego när du går in i hennes rum. 
STACEY: But when I come in and see everything out then it annoys me, so I ask her to pick up her lego and put them in her room.

ANNIKA: Och där har vi också en stor skillnad. Jag gör saker, medan hon ber vår dotter att göra saker. Vilket jag tycker är mycket, mycket bättre. Det här är ingen bedömning. Jag bara konstaterar att dom flesta kvinnliga vänner ...

STACEY: That's why you guys get so burnt out here.

ANNIKA: That is very possible!

STACEY: You have this amazing sense of responsibility for the entire world. When your daughter is sitting there and she's a foot away from water and she says: „Mama, can I have water?» you walk up to the table and you give her water. Get your own damn water!

AN N I KA: Jag håller fullständigt med dig. Jag säger bara att jag har det här kvinnliga gisslet i mig. Att jag gör saker av bara farten.

Som vi kan se kan Staceys städovilja, trots irritationen den skapar, tolkas som ett närmast sunt uppror mot det »kvinnliga gissel« Annika säger sig vara insocialiserad i. Att vägra befatta sig med det kvinnor i alla tider tvingats ta ansvar för beskrivs som klarsynthet och civilkurage, snarare än en osolidarisk hållning gentemot sin partner. En möjlig tolkning är alltså att jämställdhetsdiskursen helt enkelt får Staceys ovilja att framstå som smått feministisk, medan Annika sitter kvar med Svarte Petter på hand.

Att Stacey kommer från USA, får hennes attityd att tolkas utifrån ytterligare andra parametrar. Hon har, genom sin position som »utlänning», tillgång till en relativiserande blick som ställer invanda antaganden på ända. När hon föreslår att »kvinnor- 
na här«, genom att "ta ansvar för hela världen«, blir utbrända är det inte enbart kön hon lokaliserar som problemet, utan även kulturella och nationella mönster. Svenska kvinnor lever inom en jämställdhetsdiskurs som inte enbart stipulerar en jämlik arbetsfördelning mellan man och kvinna, utan även att jobbet ska utföras inom familjen. Staceys lösning är snarare att strunta i jobbet och leja ut det till andra. Låta dottern hälla upp sitt eget vatten, Annika ta disken och anlita städhjälp.

Intressant i detta sammanhang är att Staceys utomstående blick på den svenska jämställdheten tycks rimlig och till och med framsynt - just på grund av hennes position som relativt ung, lesbisk kvinna från USA. Hade hon istället varit en äldre heterosexuell man med ursprung i ett icke-västerländskt land, hade hennes städvägran förmodligen tolkats annorlunda. Istället för att framstå som potentiellt modern, framsynt och feministisk, skulle en sådan person troligen avfärdats som gammaldags och hopplöst bakåtsträvande. Som postkoloniala feministiska forskare påpekat är den svenska jämställdhetsdiskursen nämligen inte en neutral konstruktion. Snarare lyfter den fram det heterosexuella, etniskt svenska och tvåsamma paret med (ett »lagom» antal) barn som ett ideal, samtidigt som människor från andra delar av världen (och alldeles särskilt icke-västliga länder) tenderar att beskrivas som patriarkala, med icke-moderna, traditionella familjemönster och värderingar (se t.ex. de los Reyes och Mulinari 2005, Carbin 2010). Det är alltså Staceys kön, sexualitet, ålder och nationalitet som, i det jämställda Sverige, gör det både möjligt och begripligt för henne att tala om städning som hon gör. Samtidigt synliggör hennes uttalanden hur konstruktioner av jämställdhet i Sverige är synnerligen beroende av plats, tid och position. 
Städhjälp som lösning

Det blir också tydligt hur den jämställdhetsmodell som både Annika och Stacey indirekt refererar till är av en specifik sort, med vidare politiska implikationer. Som läsaren säkert noterat bygger nämligen Staceys icke-städande på att hon antingen lämnar jobbet till sin sambo - eller anlitar professionell hjälp. Staceys och Annikas lösning på städproblemet är, allt som oftast, det senare. De har, sedan flera år tillbaka, en städerska som kommer en gång varannan vecka. Annikas förklaring till detta är att hon vägrar att vara den "gnällkärring» som den ojämlika arbetsdelningen annars hade fătt henne att bli. Vi skulle kunna säga att de helt enkelt löser jämställdhetsproblemet - det problem som innebär att personen med en traderad blick och känsla för smutsen blir städansvarig - genom att betala en annan person för att göra jobbet.

Så har också några andra av de intervjuade paren försökt lösa städfrågan (jfr Ernsjöö-Rappe och Strannegård 2004, s. 149). Markus beskriver exempelvis hur han och Kristina, efter en massa bråk och tjafs om städnivå, arbetsinsats och initiativ, bestämde sig för att skaffa en städhjälp. Och Angelica, som lever ihop med Joel, två barn och Joels bror, beskriver hur de anlitat städhjälp - för att helt enkelt få livet att gå ihop under sommarmånaderna när säsongsarbetet är som mest tidskrävande.

ANGELICA: I sommar har vi faktiskt haft städhjälp. Det har varit oerhört skönt. Men det har varit finansierat av min arbetsgivare, för jag fick så mycket övertid så jag var tvungen att jobba mycket mer än jag förmådde. Så då sa jag till min arbetsgivare att om jag ska jobba såhär mycket får ni hjälpa mig på nåt sätt hemma. Så dom betalade en städfirma. Vi är så många som bor här på somrarna, det är som ett hotell. Det blir fruktansvärt 
smutsigt och rörigt. Dom allmänna ytorna i huset, inte uppe i vårt sovrum, men nere. Dom blir jättemycket smutsigare när man är flera. Och det var oerhört skönt, för det är jättesvårt att organisera en städning när det är djur och barn och saker och människor i olika åldrar hela tiden. Och jag mår jättedåligt när det är rörigt. Jag vet inte var jag har mina grejer då. Jag vill att det ska vara fint och rent när jag kommer hem och jag vill inte ha smulor under fötterna och sådär. Då blir jag jättetrött. Så det var jätteskönt. Jag städade ju en del på jobbet de där veckorna, så det var oerhört skönt att slippa städa även hemma. Jag var rörd till tårar första gången jag kom hem och gick in och speglade mig i kranarna i badrummet, liksom. (skratt) Hon är riktigt duktig, hon som städar här.

För Angelicas del fungerar städhjälpen som en (temporär) lösning på jämställdhetsproblemet. Förutsättningen, som hon formulerar det, för att hon under de hektiska sommarmånaderna ska kunna satsa helhjärtat på jobbet, är att en städare tar hand om smutsen som hopar sig hemma. I Angelicas fall blir städningen varken en uppgift som hennes man eller de andra samboende kan (eller bör) hjälpa till att lösa. Inte heller betalar hon och hennes man privat (något de inte ser sig ha råd med). Istället kliver arbetsgivaren in och underlättar det arbete som annars skulle fallit på Angelica att göra hemmavid.

En diskurs i förändring

Privat städhjälp i hemmet var emellertid en både komplex och laddad fråga, som i stort sett alla de intervjuade adresserade. Oavsett ekonomiska möjligheter var den övergripande inställningen att var och en ska "ta hand om sin egen skit» - en håll- 
ning som jag undersöker närmre i kapitel fem. Att anlita en städerska signalerade för många en återgång till ett icke-önskvärt patriarkalt klassamhälle. När jag exempelvis frågar Ingrid om hon kan tänka sig att betala för städning hemma svarar hon:

ING RID: Absolut inte. Det är en icke-fråga. Jag har kollegor som gör det, så det börjar komma närmare. Och den diskussionen har jag faktiskt haft med vissa av mina vänner. Men för mig är det otänkbart.

FANNY: Varför då?

IN GR ID: Varför jag inte vill betala för städning? Därför att ... Av flera skäl. För det första har jag bara med mig från mamma och mormor att sin egen skit tar man hand om själv och att jag också vill ta hand om mitt eget hem. Att det skulle kännas konstigt om nån annan kom och städade bland mina möbler. Nästan som en integritetskränkning - det här ska jag ta hand om. Men också som det här skamfyllda i att nån ska ta hand om min skit. Och för min del skulle det också ... Jag vill inte ... Det är klart att det finns en mängd serviceyrken där man betalar folk för att göra en tjänster, men för mig går gränsen vid att betala någon för att komma till ens hem, att i intimsfären ha nån som gör jobb åt en. Det tycker jag blir för nära en tjänstefolksrelation. Jag vill inte ha en sån klassmässig relation till nån.

Ingrid uttrycker åsikter som måste förstås i relation till det svenska välfärdssamhällets fokus på utjämnande av klasskillnader, alltså en politisk strävan mot jämlikhet. Men hennes tankar speglar också den skandinaviska samhällsformens specifika kombination av stat, familj och individ - vad Helene Aarseth har beskrivit som en statsunderstödd, familjecentrerad individualism - där jämställdhet är en central ingrediens. Aarseths 
poäng är att den individualisering och kulturella friställning som kännetecknar västvärlden (se t. ex. Ziehe 1986, Hochschild 2003), i de skandinaviska länderna kombineras med en refamiliarisering, med relativt lång föräldraledighet, reglerad arbetstid för småbarnsföräldrar och en jämställdhetsnorm. Hemmet och arbetet i hemmet görs således, som tidigare beskrivits, till en plats för självutveckling och meningsskapande för både män och kvinnor, på ett sätt som skiljer Skandinavien från andra västländer, med starkare tradition av att anlita människor för arbete i hemmet.

Kombinationen av jämlikhets-/jämställdhetsideal och statsunderstödd, familjecentrerad individualism skulle kunna betraktas som en möjlig förklaring till den ideologiska laddning som frågan om privat städhjälp har och har haft i Sverige (se Öberg 1999, Platzer 2007, Elin Pettersson 2013). Detta syns inte minst i den nära decennielånga debatten som rasade kring införandet av RUT-avdraget (dvs. möjligheten att göra skatteavdrag för hushållsarbete), som symtomatiskt nog kom att kallas pigavdrag. När förslaget presenterades 1997 avfärdades det som en ovälkommen, otidsenlig återgång till ett gammalt klassamhälle (något jag återkommer till i nästa kapitel).

Idag, när RUT-avdraget är infört sedan ett drygt decennium, är det emellertid möjligt att tala om en snabbt förändrad diskurs (Gavanas och Calleman 2013, s. 7). RUT betraktas numera som en lyckad reform, stödd av alla partier utom Vänsterpartiet, och användarna av RUT ökar för varje år. ${ }^{17}$ Inte minst har det kommit att formuleras som en reform i jämställdhetens tjänst.

Det anses helt enkelt inte lika laddat att anlita städhjälp i hemmet idag som för exempelvis tjugo år sedan (Gavanas och Calleman 2013, Hussénius 2014). Detta var också, som jag visat, 
något som avspeglade sig i mina intervjuer. Ingrid, som vi sett vara emot anlitande av privat städhjälp, beskriver samtidigt hur människor i hennes omgivning har andra åsikter. »Jag har kollegor som gör det, så det börjar komma närmare.»

Så, vad har då hänt med den statsunderstödda, familjecentrerade jämställdhetsinriktade individualismen, där sysslandet med hemmet blir en central aspekt av självförverkligandet för såväl män som kvinnor? Och viktigast i detta sammanhang: vad händer med den privata städningen? Ellinor Platzer (2007) ställer tidigare normer kring egenarbete och jämlikhet mot en ny sorts karriärlivsform, som hon menar är en viktig förklaring till den ökade efterfrågan på privata hushållstjänster. I familjer där båda parterna satsar på karriären (så kallade tvåkarriärhushåll) görs, skriver Platzer, mindre skillnad mellan arbete och fritid än mellan rutin och engagemang. Barnens fritidsaktiviteter, balkongodling eller renovering av köket kan således uppfattas som minst lika meningsfulla och kreativa sysslor som lönearbetet. Mer rutinartat arbete, som exempelvis städning, uppfattas däremot sällan som utvecklande och lejs därför gärna ut till andra. Kanske är det så vi ska tolka den tendens jag tycker mig uppfatta i Aarseths studie, där inredning, matlagning och umgänge med vänner och barn framstår som självutvecklande för såväl män som kvinnor, men däremot mer sällan städningen. Så är det också möjligt att tolka denna studies intervjupersoner, när de förhandlar, gör listor och försöker fördela arbetet rättvist - för att ingen ensam ska behöva dra lasset. Städningens rutinartade, repetitiva och till synes avgränsbara karaktär tycks alltså göra det alltmer rimligt för de som har råd att köpa tjänsten utifrån. 
Svensk exceptionalism

Sammanfattningsvis kan konstateras att vi har att göra med en diskurs i förändring. Från att under 196o-talet och ett antal årtionden framåt ha associerats med ett kvinnoförtryckande klassamhälle, tycks det idag mindre moraliskt laddat att anlita privat städhjälp i hemmet. Och även om de flesta av mina intervjupersoner delade åsikten att var och en ska ta hand om sin egen skit, hade flera av dem erfarenheter av städhjälp i hemmet, vid enstaka tillfällen eller regelbundet. Sverige verkar helt enkelt, på relativt kort tid, ha blivit mer att likna vid andra länder - där de som har råd köper privat städhjälp, ofta utan de moraliska dubier som tidigare kopplades till städköp.

Samtidigt tycks svenskheten och Sverige som plats fortsatt spela en viktig roll i de kulturella förhandlingarna kring vad det innebär att köpa städning eller låta bli. Som jag ska visa framöver vävs föreställningar om städning, kulturell hemvist, jämlikhet och jämställdhet samman i ett intrikat mönster, där svenskheten sätter alldeles specifika ramar för hur städköp upplevs, motiveras eller avfärdas. Marcela, som är uppväxt både i Sverige och i Latinamerika, beskriver hur hennes familj hade hembiträde under hennes barndom i Chile, något de inte hade råd med när de senare flyttade till Sverige. Hon minns hur familjen, och framför allt hennes mamma, plötsligt måste städa hemmet själv, något hon upplevde som betungande och arbetsamt. Själv har Marcela alltid städat i sitt eget hem - i Sverige. Men när hon och hennes man under ett par år bodde i Chile upplevde hon det plötsligt som både rimligt och nödvändigt att betala för städhjälp.

MARCELA: Jag och min man hade ett litet matställe, så vi lagade mat på helgerna. Och jag var gravid, jag hade en jättestor mage 
och jag började känna att jag hinner inte vara hemma och fixa med allt. Så då anställde vi nån som kom och hjälpte till.

FANNY: Och hur länge hade ni det då?

MARCELA: Tills Julia var kanske tre. Då åkte vi tillbaka till Sverige.

FANNY: Så det blir så att i Chile har man städhjälp, men inte i Sverige? Hur kommer det sig? För jag antar att ni hade liknande inkomster där som här?

MARCELA: Ja fast i Chile... Där gav jag terapi. Och för en timmes terapi kunde jag ta betalt fyrahundra, men för att nån kommer och hjälper mig sex timmar så betalar jag tvåhundra. Och då betalar jag jättejättebra. Dom flesta betalar kanske hundra. Så jag betalar dubbelt och det har jag alltid gjort. Men om jag har två, tre timmar terapi per dag har jag lätt råd med städhjälpen.

FANNY: Men här i Sverige...

MARCE LA: Här i Sverige, ja, framför allt att vi bor så litet nu, man känner att det är ingen idé. Eller, här klarar man av städningen på ett helt annat sätt. Man har mycket mer tillgång till tvättmaskin och till dammsugare. I Chile ... Jag hade också en tvättmaskin, men jag vet inte - det blir en helt annan tillvaro på nåt sätt. Det är enklare att städa här tycker jag. Jag har aldrig tänkt på att jag skulle kunna ha städhjälp här faktiskt.

Marcelas tankar om städhjälp är, som vi ser, till stora delar beroende av vilken plats hon befinner sig på. Trots att hennes familjesituation ser någorlunda liknande ut, verkar det rimligt (för att inte säga nödvändigt) att anlita städhjälp i Chile och onödigt (för att inte säga otänkbart) i Sverige. Utifrån hennes diskussion ser vi hur skillnaderna delvis kan förklaras av ekonomiska omständigheter. Marcela och hennes man har ungefär samma inkomst att röra sig med i Sverige som i Chile. Däremot 
är inkomstskillnaderna långt större i Chile än i Sverige, något som är en förutsättning för en marknad för hushållstjänster (se Nyberg 2015). Även om Marcela arbetar med liknande arbetsuppgifter i Chile och Sverige, blir det således mer möjligt för henne att anställa en annan person att sköta hemarbetet där.

Att det förefaller orimligt med privat städning i Sverige motiveras också, som vi ser, med att boendet i Sverige är mindre och därför mindre slitsamt att sköta. Men framför allt tycks det, i Marcelas resonemang, som om de olika geografiska platserna helt enkelt frammanar olika sätt att lösa städproblemet. I Sverige har Marcela, som hon beskriver det, aldrig tänkt att hon kan ha städhjälp - trots att städandet periodvis varit en källa till bråk inom familjen. I Chile använde hon däremot ganska snabbt sitt överskott av lönen till en städerska.

Ett annat exempel på hur Sverige och svenskhet blir en variabel i förhandlingar kring städning som syssla hämtar jag från en intervju med Thandi, en kvinna i fyrtioårsåldern som pendlar mellan att bo i Mali och en mellanstor svensk stad. Thandi, som är uppväxt i Sverige med en svenskfödd mamma och en pappa uppväxt i ett afrikanskt land, beskriver hur hon har svårt att anpassa sig till situationen i Mali, där de flesta med lite pengar över anställer en städhjälp.

THANDI: Vi har faktiskt försökt ha lite hjälp med städningen just, men det slutar alltid med kaos och kalabalik eftersom jag inte kan låta bli att hjälpa till att städa samtidigt. Och där är det så otroligt - det låter jättehemskt - alltså otroligt viktigt med maktrelationer. Det är nånting som förs tillbaka till slaveritiden, att det är väldigt tydligt i samhället att är man inte däruppe så är man därnere och på nåt sätt måste man ta ställning och inte ligga här i mitten och skvalpa som vi gör i Sverige hela 
tiden. Och gör man det så är man den som hamnar längst ner till slut och blir trampad på. Så det slutar alltid med att man tappar respekt och ja, sen kan det sluta precis hur som helst med allt ifrån stölder till - ja, allt möjligt kan faktiskt inträffa. Så därför har vi ingen som hjälper till med nånting. Vi försöker sköta det hela själva, vilket betyder att vi har det stökigare än andra familjer. »Svenskstökigt« kallar jag det.

Istället för städhjälp löser Thandi situationen genom att låta hemmet vara mindre välstädat än gängse standard i sitt nuvarande hemland. Att ha »svenskstökigt» fungerar inte bara som en potentiell förklaring till kulturell skillnad i städstandard. Det kan också förstås som en manifestation av ett annorlunda förhållningssätt till ojämlikhet och maktskillnad - en sorts etnifierad politisk moral.

Intressant i båda dessa intervjuer är hur svenskheten och Sverige som plats formar städningen och de potentiella städköpen på särskilda sätt. Sverige blir inte vilken plats som helst och svenskheten är inte neutral. Snarare sammankopplas den med ett jämlikt/jämställt förhållningssätt, såsom vi ser i Thandis resonemang. För Thandis del blir svenskheten en (del)förklaring till varför hon och hennes man väljer att inte anställa städpersonal i hemmet. I Catrin Lundströms (2013) studie av utlandssvenskar i Singapore används samma svenskhet snarare som argument för att svenskarna skulle vara bättre än andra arbetsgivare på plats - de behandlar inte sina »live-in-maids« lika illa som kineserna påstås göra, just för att de är svenska. En liknande logik beskriver Anna Gavanas (2006) hos de personer hon intervjuat om städköp. Trots att arbetsvillkoren i de svenska hemmen i många fall var dåliga tycktes svenskhet kunna fungera som en sorts legitimering av hushållstjänsteköpen. Själva det faktum att inter- 
vjupersonerna var svenska tänktes helt enkelt borga för en mer jämlik och icke-exploaterande relation till deras anställda.

Svenskhet tycks således kunna användas både som en förklaring till varför vissa väljer att städa hemma själva och som en sorts kravmärkning för de som köper tjänsten - något som blir intressant i relation till den förändrade diskursen kring privata städköp. Alldeles oavsett hållning i fråga om köp av hushållstjänster frammanas alltså Sverige och svenskheten som en särskilt jämlik och jämställd nation och nationalitet.

Städningen, jämställdheten och tiden

De politiska argumenten för skattesubventionerad städning har (förutom att motverka svartarbete och skapa fler arbetstillfällen för outbildade) varit att möjliggöra för kvinnor och män att på mer lika villkor kombinera familj och arbete. Slagord som använts i debatten är individuell valfrihet, ökad sysselsättning och - just - jämställdhet (Gavanas 2013, s. 85). Trots att frågan varit synnerligen omdebatterad (se t. ex. Kvist 2013, Gemzöe 2015) har den alltså i många sammanhang framställts som en möjlig lösning på jämställdhetsproblemet, något som illustreras i några av intervjuerna.

Skattesubventionerad städning i hemmet som en jämställdhetspolitisk åtgärd må fungera för vissa människor, i vissa hem, med vissa ekonomiska omständigheter. Samtidigt aktualiseras frågan jag ställde i kapitlets början: hur skapas jämställdhet utifrån städning som praktik? Hur ser den jämställdhetsmodell ut där städhjälp är en lösning på problemet? Och hur kan ett temporalitetsperspektiv bidra med synsätt på dessa frågor?

Som jag visar genom kapitlet är städning och jämställdhet intimt sammanvävda - och kanske extra mycket så i Sverige. 
Trots en (delvis) statsunderstödd familjecentrerad individualism, där hemmasysslorna framstår som potentiellt meningsskapande och självutvecklande, kan städningen pekas ut som en av de sysslor kvinnor helst av allt vill slippa göra själva - och samtidigt den syssla där män är som mest obenägna att ta sin del. Trots mäns under senare år ökade insatser i hemmet gör kvinnorna fortfarande merparten av jobbet och i de fall där män delar lika faller det allt som oftast på kvinnan att vara såväl arbetsledare som initiativtagare.

Inte minst är städningen symboliskt laddad med föreställningar om just det jämställda livet i den heterosexuella familjen. Att dela lika på städningen framstår för många som ett ideal att förhålla sig till, något som i viss mån tycks mer komplicerat för kvinnorna än för männen. För medan männen i vissa fall använde sig av jämställdhet som en viktig motivationsgrund för att ta ett extra tag med dammsugaren, kunde jämställdhetsdiskursen upplevas som i det närmaste ett ok för vissa av kvinnorna. Medan männen potentiellt kunde vinna i anseende och status på att framstå som jämställda, hamnade kvinnorna oftare i sitsen "damned if you do - and damned if you don't». Kvinnors övergripande ansvar och blick för dammet i hörnen kunde lätt läggas dem till last, eftersom de även framstod som ansvariga för att leva i en jämställd relation. Så kom det sig att vissa av de intervjuade kvinnorna helt enkelt lät bli att prata arbetsdelning med sin manliga partner, trots att de inte var nöjda med sin situation - för att inför sig själva slippa att framstå som ojämställda och därigenom misslyckade.

Jag har också visat hur tiden är central i diskussionerna om jämställdhet och städning. Med hänvisning till städningens tid och tidsåtgång mäts och värderas det jämställda heterosexuella familjeprojektet. Detta sker inte enbart bland intervjuperso- 
nerna, utan syns också i jämställdhetsstatistik, statliga utredningar på området liksom i det ökade talet om »livspussel« och »work-life-balance» (jfr Jordansson och Lane 2018, s. 19). Trots att insats räknad i tid inte nödvändigtvis fångar arbetets art - som vi sett handlar det om så mycket mer än att varannan vecka dra en dammsugare över köksgolvet - framställs städningen härigenom som en avgränsbar och rutinartad aktivitet. Räknandet i minuter och timmar gör sysslan helt enkelt mer möjlig att både sälja och köpa, i jämställdhetens namn. Åtminstone för de som har den ekonomiska möjligheten.

I Sida vid sida undersöker Katharina Tollin (2011) de senaste trettio årens riksdagsdebatter om jämställdhet - ett politikområde som varit på frammarsch under senare år med initiativ som varannan damernas, jämställdhetslagen och pappamånader. Tollin visar hur den förhärskande definitionen av jämställdhet som renodlade »könsfrågor« ingalunda är en neutral sådan. Snarare är den ett resultat av politiska konflikter mellan vänster och höger, där de borgerliga partierna under de senaste decennierna vunnit tolkningsföreträdet. Jämställdhetspolitiken har, sedan 1980-talet och framåt, alltmer kommit att handla om frågor som könsdiskriminering, likabehandling och representation. Vad som hänt, menar Tollin, är att frågan om ekonomisk jämlikhet successivt sorterats bort från »kvinnofrågan«, det vill säga att kön görs till en särskild orättvisa skild från klass. Detta resulterar, enligt Tollin, i att jämställdhetspolitiken mer eller mindre blivit samstämmig med en nyliberalt orienterad samhällsmodell baserad på individuella rättigheter, nedskärningar av offentlig sektor, managementmodeller och individuell lönesättning - där jämlikhet som ideal successivt gjorts irrelevant.

Enligt Wendy Brown (2008) beror liberalismens genomslag i världen inte på att människor är särskilt nöjda med nylibera- 
la värden. Snarare, menar hon, handlar det om att andra alternativ inte framstår som möjliga eller tänkbara. Liberalismens ledord som valfrihet, individualitet och likabehandling har, i västvärlden, kommit att bli synonyma med modernitet och framåtskridande. Snarare än en specifik ideologisk position, framstår de som självklara och icke-ifrågasättbara. En liberalt definierad jämställdhet blir därigenom en sorts, med Chantal Mouffes (2005) formulering, post-politik. Med det menas en hållning som tycks självklar just för att de underliggande konflikterna sopats under mattan.

De underliggande konflikterna skulle, i detta sammanhang, kunna lokaliseras till klass. Det är helt enkelt mer möjligt att göra sig av med den arbetsamma och ovälkomna städsysslan för de som lever i par (med två inkomster), har högre inkomst och tillsvidareanställning än för den ensamstående föräldern med en lågbetald timanställning. ${ }^{18}$ Bland mina intervjupersoner var det också många som inte hade ekonomisk möjlighet att leja ut vardagsstädningen för pengar, i synnerhet de som själva arbetade med städning. Att formulera avdragsgill städhjälp i hemmen som en fråga om jämställdhet handlar därför om klass (och i förlängningen etnicitet/rasifiering) lika väl som om kön. Inte minst handlar det om tid. Betraktar vi, med Sarah Sharma (2014), även tid som en fråga om makt blir det nämligen rimligt att fundera över vems tid som värderas och räknas i samhället. Är det den överarbetade högutbildade kvinnans behov av vila och kvalitetstid med barnen som prioriteras, hennes mans behov av att arbeta längre dagar utan att riskera bråk om hemarbetet när han kommer hem eller den ensamboende pensionären utan ekonomiskt utrymme att betala för städhjälp? Är det kvinnan som arbetar med städning i andras hem vi har för ögonen: hon som lämnat sitt vardagsliv, vänner och familj i hemlandet 
för att tjäna pengar på annan ort och aldrig skulle ha råd att anställa någon för att ta hand om smutsen hemmavid?

Städning blir, i detta sammanhang, att betrakta som en jämställdhetens Svarte Petter - en sorts bortkastad tid att bråka om eller helt enkelt, för den som är privilegierad, köpa sig fri från. Mer övergripande genererar städningen, med ett temporalitetsperspektiv, vidare frågor om vad människors olika tillgång till tid får för konsekvenser för ett demokratiskt samhälle. 